\title{
Urban Ecosystem-Level Biomimicry and Regenerative Design: Linking Ecosystem Functioning and Urban Built Environments
}

\author{
Eduardo Blanco $^{1,2, * \mathbb{C}}$, Maibritt Pedersen Zari ${ }^{3}{ }^{\mathbb{D}}$, Kalina Raskin $^{2}$ and Philippe Clergeau ${ }^{1}$ \\ 1 Centre d'Écologie et des Sciences de la Conservation (CESCO UMR 7204)/MNHN, 43 Rue Buffon, \\ 75005 Paris, France; philippe.clergeau@mnhn.fr \\ 2 Ceebios, 62 rue du Faubourg Saint-Martin, 60300 Senlis, France; kalina.raskin@ceebios.com \\ 3 School of Architecture, Victoria University of Wellington, VS 2.07, Te Aro Campus, 139 Vivian Street, \\ Wellington 6011, New Zealand; maibritt.pedersen@vuw.ac.nz \\ * Correspondence: eduardo.blanco@ceebios.com
}

check for

updates

Citation: Blanco, E.; Pedersen Zari, M.; Raskin, K.; Clergeau, P. Urban Ecosystem-Level Biomimicry and Regenerative Design: Linking Ecosystem Functioning and Urban Built Environments. Sustainability 2021, 13, 404. https://doi.org/ $10.3390 /$ su13010404

Received: 9 December 2020 Accepted: 30 December 2020 Published: 4 January 2021

Publisher's Note: MDPI stays neutral with regard to jurisdictional clai$\mathrm{ms}$ in published maps and institutional affiliations.

Copyright: (C) 2021 by the authors. Licensee MDPI, Basel, Switzerland. This article is an open access article distributed under the terms and conditions of the Creative Commons Attribution (CC BY) license (https:// creativecommons.org/licenses/by/ $4.0 /)$.

\begin{abstract}
By 2050, 68\% of the world's population will likely live in cities. Human settlements depend on resources, benefits, and services from ecosystems, but they also tend to deplete ecosystem health. To address this situation, a new urban design and planning approach is emerging. Based on regenerative design, ecosystem-level biomimicry, and ecosystem services theories, it proposes designing projects that reconnect urban space to natural ecosystems and regenerate whole socioecosystems, contributing to ecosystem health and ecosystem services production. In this paper, we review ecosystems as models for urban design and review recent research on ecosystem services production. We also examine two illustrative case studies using this approach: Lavasa Hill in India and Lloyd Crossing in the U.S.A. With increasing conceptualisation and application, we argue that the approach contributes positive impacts to socio-ecosystems and enables scale jumping of regenerative practices at the urban scale. However, ecosystem-level biomimicry practices in urban design to create regenerative impact still lack crucial integrated knowledge on ecosystem functioning and ecosystem services productions, making it less effective than potentially it could be. We identify crucial gaps in knowledge where further research is needed and pose further relevant research questions to make ecosystem-level biomimicry approaches aiming for regenerative impact more effective.
\end{abstract}

Keywords: ecosystem services production; ecosystem-level biomimicry; urban regenerative design; sustainable urban design; urban ecosystems

\section{Introduction}

Cities are the primary habitat of human beings. By 2050, 68\% of the world's population will likely live in urban centres, representing more than 6 billion urban dwellers [1]. Human settlements are dependent on ecosystem services; that is, the natural benefits, goods, and services derived from ecosystems. Simultaneously, urbanisation and urban activities are a prominent cause of ecological process simplification, biodiversity loss, and ecosystem health reduction [2]. Anthropic alterations to ecosystems reduce their capacity to create benefits, goods, and services that are both vital to and are expected by society [3].

To engage with these challenges, regenerative design aims to create urban projects that promote positive impacts, allowing social and ecological systems to co-evolve and thrive $[4,5]$. In this context, there is significant evidence that a new regenerative urban design approach is emerging which relies on ecosystem-level biomimicry theories to integrate and more fully take account of ecosystem health alongside urbanisation processes, and therefore contributes to the possibility that the regenerative paradigm shift can 'scale jump' to beyond the building scale to the urban scale [6,7].

Biomimicry draws upon emulation of, and knowledge transfer from, living organisms and whole ecosystems to find solutions to human problems [8]. In the built environment 
disciplines, its application has been growing at the architectural scale, with the aim of sustainable innovation $[9,10]$. Several buildings have already employed this approach, going through formal biomimetic development methods for design, and integrating functional solutions to meet sustainable development challenges, as the Eastgate Building in Harare (Zimbabwe), and the Council House 2 (CH2) in Melbourne (Australia) [9,11]. At the urban scale, the application of biomimicry has been less explored [12]. Where it is apparent, design inspiration typically draws upon ecosystems rather than individual organisms [10].

Ecosystem-level biomimicry has the potential to facilitate regenerative design at the urban scale $[7,11]$. It can have a significant role at the project design phase, guiding design teams to conceive of projects that can work in symbiosis with local ecosystems, allowing net positive outcomes, both ecologically and socially, along with the reconnection and coevolution of urban and ecological systems [11,13]. The aim is to design urban projects or developments that reconnect, emulate, or integrate their functioning with local ecosystems and have a measurable positive impact on those $[7,11]$. Ecosystemlevel biomimicry for regenerative urban design employs an understanding of ecosystem patterns and functioning as models for urban space design. It relies on ecosystem metrics and ecosystem services assessments as the main inputs into the design process $[10,11]$.

With relevant theoretical conceptualization as a basis [5,11,14], ecosystem-level biomimicry for regenerative urban design has increasing examples of built application $[7,13,15]$. However, even if applied in urban projects with documented results [7], these methods still lack a deeper understanding of ecological theories based on ecosystem functioning [11,16], leading to a simplistic understanding of the ecosystem model. We argue that the approach could be expanded to consider current knowledge and developments related to ecosystem services production, such as the ecosystem services cascade theory and the ecological integrity concept.

\section{Methodology}

In this paper, we analyse the evolution of regenerative urban design practices that use ecosystems as models. We also review recent research on ecosystem services production and assessment and discuss the application of ecosystem-level biomimicry for regenerative urban design in two urban projects. The literature review was realized using a snowball method [17]. The two case analyses and discussion are based on landscape and urban project case studies method [18] and logical argumentation [19]. These steps allow us to understand trends in practice and identify opportunities for further development of this approach, so that regenerative practices can be translated from primarily the building scale, to larger urban and regional scales.

\section{Ecosystems as Models in Urban Planning and Design Practices}

The formal integration of urban spaces and natural ecosystems in urban planning and design dates from the 19th century, with work from planners and researchers like George Perkins Marsh, John Wesley Powell, Patrick Guedes, Sir Howard Ebenezer, and Frederick Law Olmsted [20]. These works firstly emphasised the health and recreational properties of green and blue infrastructures alongside aesthetics in the design of urban parks [21].

In the 1960s, McHarg further developed these concepts, proposing that humandesigned landscapes should replicate natural systems' performance and logic [22]. McHarg argued that a deep understanding of local ecological processes is fundamental before embarking on the design of any landscape or urban project [23]. McHarg's 1969 Design with Nature contributed to the basis of "landscape suitability analysis" approaches [20,23]. These are the foundations of modern urban and landscape design practices such as landscape ecology and geodesign that use ecological system comprehension at some level [20,24]. Within these methods, ecosystems are studied to determine the optimal location of a project and uses of a given area. From a methodological perspective landscape suitability analysis relies on an inventory of locally relevant ecosystems, usually compiled through aerial images and remote sensing data. This inventory is organised and analysed in a layer-cake 
model, superimposing relevant ecological factors to create a suitability map. Finally, this analysis, based on macroscale ecosystem information is used to assess the fitness of uses for a particular area in order to minimize negative impacts [20,24]. It is important to note that remote sensing is one inventory method used on landscape suitability analysis and ecosystems services assessments, among several others that are also relevant and complementary, as field inventory methods and other qualitative and socio-cultural approaches [25].

John Tillman Lyle proposed, in 1994, the regenerative design concept as a tool for sustainable urban development. Lyle's work questioned urban systems' linearity compared to ecosystems, anchoring his work in ecology and ecosystems comprehension [26]. He suggested that it would be possible to build artificial urban spaces with a circular logic by reincorporating the essential elements of life, such as energy conversion, water treatment, and nutrient cycling in human designed urban spaces [26]. To address the degeneration of natural ecosystems, Lyle proposed twelve central strategies for promoting the regeneration of urban spaces, mainly taking ecosystem functions and processes as models for exploration and emulation [26].

In the same vein, the contemporary practice of regenerative design, largely popularised by the research and practice of Bill Reed and various co-authors [27], proposes a shift from a mechanical understanding of urban systems to an ecological and holistic perspective [14]. It challenges traditional methodologies and tools for sustainable urban design, putting ecosystem functioning and patterns of the site at the centre of the design process, aiming for the mutually beneficial coevolution of social and ecological systems $[4,5,11,14,27]$.

In this context, ecosystem-level biomimicry for regenerative urban design represents a new design approach, relying on holistic knowledge transfer from ecology to built environment design disciplines. Pedersen Zari formalised the first methodological urban design framework using these concepts, called Ecosystem Services Analysis (ESA), and tested the approach at the city scale $[7,11]$. ESA draws on ecosystem services assessment to understand how ecosystems function and attempts to translate this knowledge into the field of architectural and urban design. The framework consists of four steps: first is a preliminary evaluation of the ecosystem services generated from the original ecosystem that existed on the same site as the current urban setting in question; second is an assessment of ecosystem services currently generated on-site; third is a comparison between the results of steps 1 and 2. This allows elaborating performance goals and objectives based on the sitespecific ecological reality; fourth is a search for and implementation of design, technology, and behaviour change solutions to achieve the defined objectives. This is followed by an evaluation, and if need be, a re-design stage [11]. Pedersen Zari's framework lists various metrics that can be used in the calculation processes, such as: vegetation-covered areas and their capacity to store and sequester carbon; air pollution types and rates removed by vegetation; annual rainfall; and nutrient cycling capacities among others. These metrics are useful to understand the evolution of ecosystem functioning and ecosystem services available in an urban area and allow designers to define strategies to regenerate and/or integrate with them and thus create positive impacts on socio-ecosystems $[7,11]$.

Comparing conventional urban and landscape design approaches that use ecosystem information in the design process, such as landscape suitability analysis and derived methods, and ecosystem-level biomimicry for regenerative design practice, we can observe that ecosystems are used as models in design with different perspectives. Ecosystem-level biomimicry offers an opportunity to deeply integrate ecological information into urban design, going beyond analysis of how the project impacts ecosystems and how to minimise this impact. Table 1 summarizes the main differences between these approaches identified in our review by using three main criteria. 
Table 1. Comparison between landscape suitability analysis (and derived approaches) and ecosystemlevel biomimicry for regenerative urban design.

\begin{tabular}{lcc}
\hline Landscape Suitability Analysis & $\begin{array}{c}\text { Ecosystem-Level Biomimicry } \\
\text { 1. } \begin{array}{l}\text { Objective of the } \\
\text { ecosystem analysis }\end{array}\end{array}$ & $\begin{array}{c}\text { Analyse the fitness of a project for } \\
\text { a specific area; select urbanisation } \\
\text { strategies that reduce negative } \\
\text { environmental impacts [23,24]. } \\
\text { rely on ecological data to } \\
\text { deeply connect urban systems } \\
\text { with ecological system } \\
\text { patterns; reduce negative } \\
\text { environmental impacts and } \\
\text { catalyse positive ones for both } \\
\text { social and ecological systems } \\
\text { [10,11]. }\end{array}$ \\
$\begin{array}{lll}\text { Level of details and } \\
\text { type of data used in } \\
\text { the ecosystem model }\end{array}$ & $\begin{array}{c}\text { Macroscopic information, using } \\
\text { aerial and remote sensing data } \\
\text { [20,23,24]. }\end{array}$ & $\begin{array}{c}\text { Detailed information using } \\
\text { ecological indicators [7,11]. }\end{array}$ \\
$\begin{array}{l}\text { Analysis of the } \\
\text { ecosystem model } \\
\text { information }\end{array}$ & $\begin{array}{c}\text { Ecosystem information is treated } \\
\text { discretely in a cake-layer } \\
\text { approach [23,24]. }\end{array}$ & $\begin{array}{c}\text { Ecosystem information is } \\
\text { treated holistically with an } \\
\text { emphasis on understanding } \\
\text { relationships, synergies and } \\
\text { trade-offs [7,10,11,13]. }\end{array}$ \\
\hline
\end{tabular}

Source: Developed by the authors.

Despite the conceptual and theoretical development of Pedersen Zari's framework and others related but different, such as Ecological Performance Standards by Biomimicry 3.8 [13], few built urban projects engaged in sustainable development practices have applied the general idea of emulation of ecosystem services provision. However, examples do exist, and studying these allows an evaluation of the practical application of ecosystemlevel biomimicry for regenerative urban design $[7,10,11]$. The Lavasa Hill and the Lloyd Crossing projects are further discussed in this paper for this purpose.

\section{Understanding Ecosystems and Ecosystems Services Provision}

In order to critically evaluate ecosystem-level biomimicry for regenerative urban design, it is essential to understand and explore related appropriate contemporary research in ecology and ecosystems. Following Odum's definition in 1969, ecosystems are a biological organisational unit, made up of all organisms in a given area, that interact with physical space and abiotic conditions and substances, and lead to a flow of energy and material cycles within it [28].

Ecosystem services, the entry point to translate ecosystem functioning in the design framework proposed by Pedersen Zari [11], are the benefits that human society derives directly or indirectly from the functioning of ecosystems, which contribute to wellbeing [3]. The concept, developed in the 1990s, is a framework to facilitate understanding human dependencies on ecosystems [29]. Research on ecosystem services has developed widely across multiple disciplines, and the concept has become essential in public policy and conservation sciences [30]. The application of ecosystem services knowledge to urban design and planning is a key emerging research topic related to the ecological transition of cities [22]. However, the generation of ecosystem services in urban settings remains a concept that is difficult to operationalise at the urban scale (suburbs, neighbourhoods, streets). Difficulties are commonly related to the lack of data, the theoretical aspect of the approach, and the lack of homogeneity between the indicators and methodologies used among different studies [31-33]. These difficulties also relate to the application of the ecosystem-level biomimicry for regenerative urban design.

To provide a standardised conceptualisation of ecosystem services production, the Ecosystem Services Cascade Framework was proposed by Haines-Young and Potschin in 2010 [30,34,35]. The cascade, illustrated in an adapted form in Figure 1, defines and 
organises elements critical for the provision of ecosystem services. The framework starts with the biophysical structures, the biotic and abiotic elements that make up ecosystems and their patterns, and ecosystem processes and functions, which are ecological interactions that take place over time in an ecosystem. They are followed by the services themselves, which are flows of benefits created by ecosystem structures, processes, and functions. Finally, ecosystem services can be converted in goods and benefits for society, that are the material or immaterial results of this chain which contribute to human wellbeing [30,35].

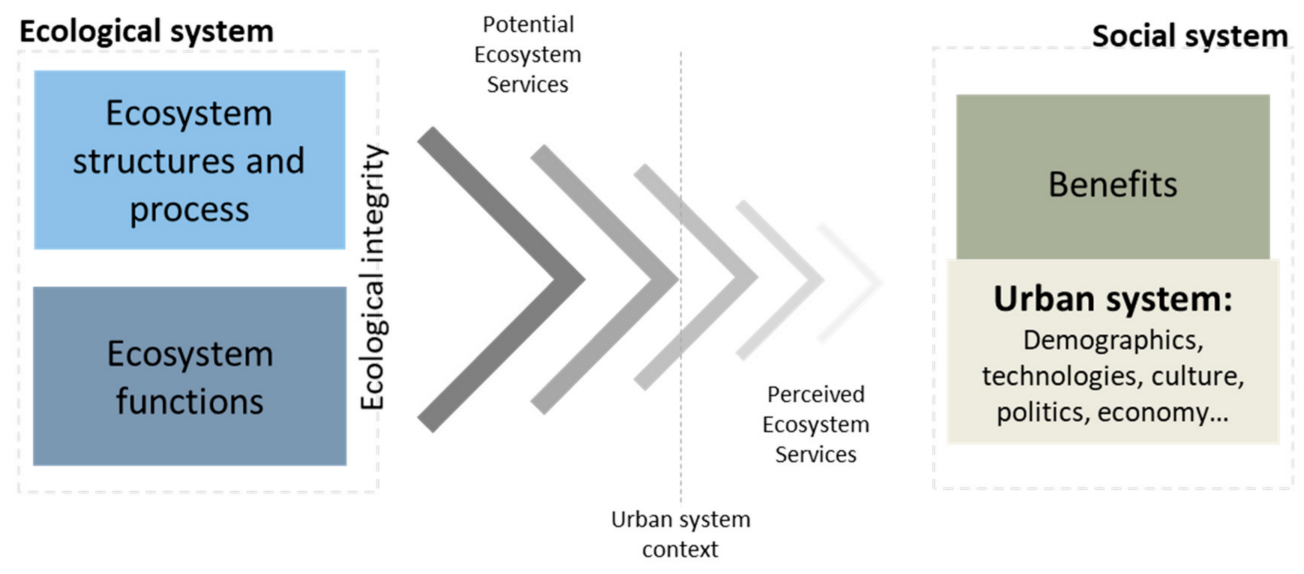

Figure 1. Ecosystem services cascade for an urban socio-ecosystem perspective. Ecosystem structure is the starting point of ecosystem services production. Adapted from [30,35].

The Common International Classification of Ecosystem Services (CICES), which is a standard classification of ecosystem services, uses the ecosystem services cascade concept to propose a broad and hierarchical classification of ecosystem services [31], and introduces homogeneity as part of the classification [31,32].

The Ecosystem Services Cascade Framework throws light on the importance of the ecosystem's biophysical structure to the provision of ecosystem services. Kandziora et al. (2013) explored the relationships and correlations between ecosystem services production and the different elements of the cascade. The authors also highlighted the importance of the biophysical structure in this process and proposed that the concept of ecological integrity could be useful to describe the state of an ecosystem and allow assessment of ecosystem services production [36,37]. While biodiversity is responsible to high levels of ecosystem services provision, urban stakeholders still struggles to integrate this variable comprehensively on urban areas. This fact relates to potential conflict of interests in land use as well as potential ecosystem disservices felt by urban dwellers, as allergies, accident potential related to biodiversity and damages on infrastructure [38,39].

Müller defines an integer ecosystem as an ecological system that can maintain its self-organisation capacity and ecological process after small disturbances, continuing its development [37]. Kandziora et al. proposed an indicator framework to assess ecosystems' ecological integrity and their inherent production of ecosystem services. The framework is composed by eight criteria: exergy capture, entropy production, storage capacity, nutrient cycling, biotic water fluxes, metabolic efficiency, spatial heterogeneity, and biological diversity. Among these variables, biodiversity, spatial heterogeneity, and exergy capture seem to have central importance for ecosystem functioning and ecosystem services production [36].

This overview of ecosystem services production highlights the links between ecosystem biophysical structures, their health and integrity, and ecosystem services provision. Ecosystem structures, processes, and functions have a leading role in facilitating ecosystem services supply [36]. These ecosystem services are a consequence of healthy and integer ecosystems [30]. This understanding of ecology allows us to infer that the theoretical formulation and practice of ecosystem-level biomimicry for regenerative urban design that focuses solely at the end of the ecosystem services cascade, lacks in depth compre- 
hension of the ecological processes behind ecosystem services production. It follows that applying such concepts to urban design, even if inspirational and through a sustainable or regenerative lens, may remain metaphorical, and not as effective as potentially it could be.

\section{Case Studies: Using Ecosystem-Level Biomimicry to Catalyse Urban Regeneration}

The following case studies were selected because both urban scale projects use ecosystem-level biomimicry in the design phase. They are used here to contrast theory with biomimetic urban design practice. Both case studies have a goal of regenerative impact. Also, both projects reached some level of implementation over time, rather than remaining at a proposed or conceptual level. We acknowledge the differences in these projects' context, mainly regarding size, biomes, and cultures, and thus we concentrate on how ecological information has been used in the design process.

\subsection{The Lavasa Hill Project, Maharashtra, India}

Lavasa is a planned city in Maharashtra state in India's Mumbai-Pune region, covering over 2000 ha of land. Part of it has been designed or re-designed using the Ecological Performance Standards framework devised by Biomimicry 3.8 (Missoula, USA, a consultancy company offering biological intelligence consulting, and professional training) $[10,13,40,41]$. Even if not wholly built due to several environmental, equity, and financial management controversies [40] not discussed in this paper, the design approach finds inspiration from local monsoon ecosystems and organisms to solve sustainable urban design challenges, mostly related to rainwater management and erosion control.

Through an ecological diagnostic process, engaging urban designers and ecologists, the HOK Architects and Biomimicry 3.8 design team identified six essential ecosystem services for the site's ecological functioning rendered by the local forest that were relevant to the development of the urban project in the area $[10,41]$. They were:

- water collection;

- solar gain;

- carbon sequestration;

- water filtration;

- evapotranspiration; and

- $\quad$ nitrogen and phosphorus cycling.

This ecosystem services identification was the first step of Lavasa ecosystem-level biomimetic process. The team aimed to design an urban project that could recreate these ecosystem services, while simulating local ecosystem functions. To translate this into tangible design strategies, the design team focused mainly on understanding local water cycles and identified that in the local ecosystem $20-30 \%$ of rainwater evaporates through the tree canopies, $60-65 \%$ infiltrates into the soil, and $10-15 \%$ is accounted for as runoff [41].

These metrics guided the designers to conceive built infrastructures that could replicate these water-related ecosystem services, facilitating, for example, evaporation on the "built canopy". Through infiltration and managing runoff, values near those derived from the native forest could be reached in the built environment. Among the technical solutions applied were: rooflines designed to create wind turbulence to facilitate evaporation; green roofs to slow water flows; infiltration swales; massive revegetation using hydroseeding; and dams to store rainwater. These solutions contributed to the on-site water management and a slowing down of rainwater runoff to reduce soil erosion, an identified local major issue [10]. This approach aimed to reduce the overall ecological impact of the loss of existing forest due to built environment caused land-use change [10,41], by recreating water-related ecosystem processes and ecosystem services through mimicking strategies seen in the local ecosystem.

\subsection{The Lloyd Crossing Project, Oregon, USA}

Lloyd is a mixed-use district located in Portland (OR, USA). A sustainable urban development plan was proposed for the existing and mixed-use neighbourhood of over 
800 ha in 2004. The plan used a design approach that finds inspiration in local ecosystem patterns to catalyse ecological, social, and economic regeneration at the district level. The project was tasked with pushing the limits of sustainable urban design and deeply integrating the urban system with surrounding ecosystems in a symbiotic way, thus going beyond LEED Platinum performance, which at the time was the most challenging building metric related to sustainability [42]. Mithūn and Greenworks designers used the notion of "pre-development metrics" derived from the local ecosystem (which has similar logic to the ecosystem-level biomimicry approach proposed by Pedersen Zari [11]), to build site-specific ecological comprehension that guided the long term neighbourhood-scale sustainable urban strategy [11,42]. Thirteen ecological metrics were assessed, including vegetation cover, wildlife diversity, water flows, total solar energy input, and energy converted to biomass through photosynthesis (Table 2). The design team assessed two scenarios: 1. the pre-development ecological situation, which was a native conifer forest ecosystem; 2. the urban ecosystem existing at the time. With a comparative approach, the designers identified the gaps between both scenarios. This information was used to define ecological performance targets and devise development strategies over long time periods for the urban development plan. Five structuring tenets of the project were defined using these metrics, aiming to have a positive impact on the whole socio-ecosystem: (1) restore habitat and vegetation canopy; (2) rely only on the rainwater available on site; (3) rely only on the solar energy available locally; (4) preserve urban density; and (5) ensure carbon neutrality [42,43]. The project broke down these tenets into several specific long-term strategies and actions for the neighbourhood. One example was the green canopy increase. In the original ecosystem, vegetation covered $90 \%$ of the area, as compared to $14.5 \%$ at the time of the project design. $30 \%$ coverage was the goal of the project over time. To reach this objective, the project relied on strategies like green street design, new public green spaces, green roofs, and connectivity with the existing urban green grid in the area. Other strategies were the increase of habitat through major green area restoration and riverbank restoration. Also important was the optimisation of water flows, respecting the available rainwater on-site through water consumption reduction, and rainwater collection, treatment, and storage. A similar strategy was proposed regarding energy, focusing on solar energy production and performance improvement for buildings, limiting consumption to match locally available resources. Finally, the project identified 15 benefits that the proposed actions could have for society including improving wellbeing, creating habitat for wildlife species, and regulating pollution, that can also be understood as ecosystem services.

Table 2. Comparison between the Lavasa Hill and the Lloyd Crossing case studies.

\begin{tabular}{|c|c|c|}
\hline & Lavasa Hill & Lloyd Crossing \\
\hline Location & Mumbai-Pune region, India & Portland, Oregon, USA \\
\hline $\begin{array}{l}\text { Motivation for the } \\
\text { biomimetic approach }\end{array}$ & $\begin{array}{l}\text { "To prevent this [ecosystem disturbance] } \\
\text { from happening, the design team established } \\
\text { strict ecological performance standards and } \\
\text { specific strategies for maintaining each } \\
\text { ecosystem service" [41]. }\end{array}$ & $\begin{array}{c}\text { "The Lloyd Crossing Sustainable Urban Design Plan } \\
\text { looks at an urban ecosystem in which individual } \\
\text { properties and the neighborhood public realm function } \\
\text { together as an environmentally low- impact unit with } \\
\text { high economic potential" [43]. }\end{array}$ \\
\hline Ecosystem used as model & Moist deciduous forest [41]. & Mixed-conifer forest [42]. \\
\hline $\begin{array}{l}\text { Main ecological concepts } \\
\text { used in the biomimetic } \\
\text { design process }\end{array}$ & Ecosystems services [41]. & Biophysical structure and ecosystem processes [43]. \\
\hline
\end{tabular}


Table 2. Cont.

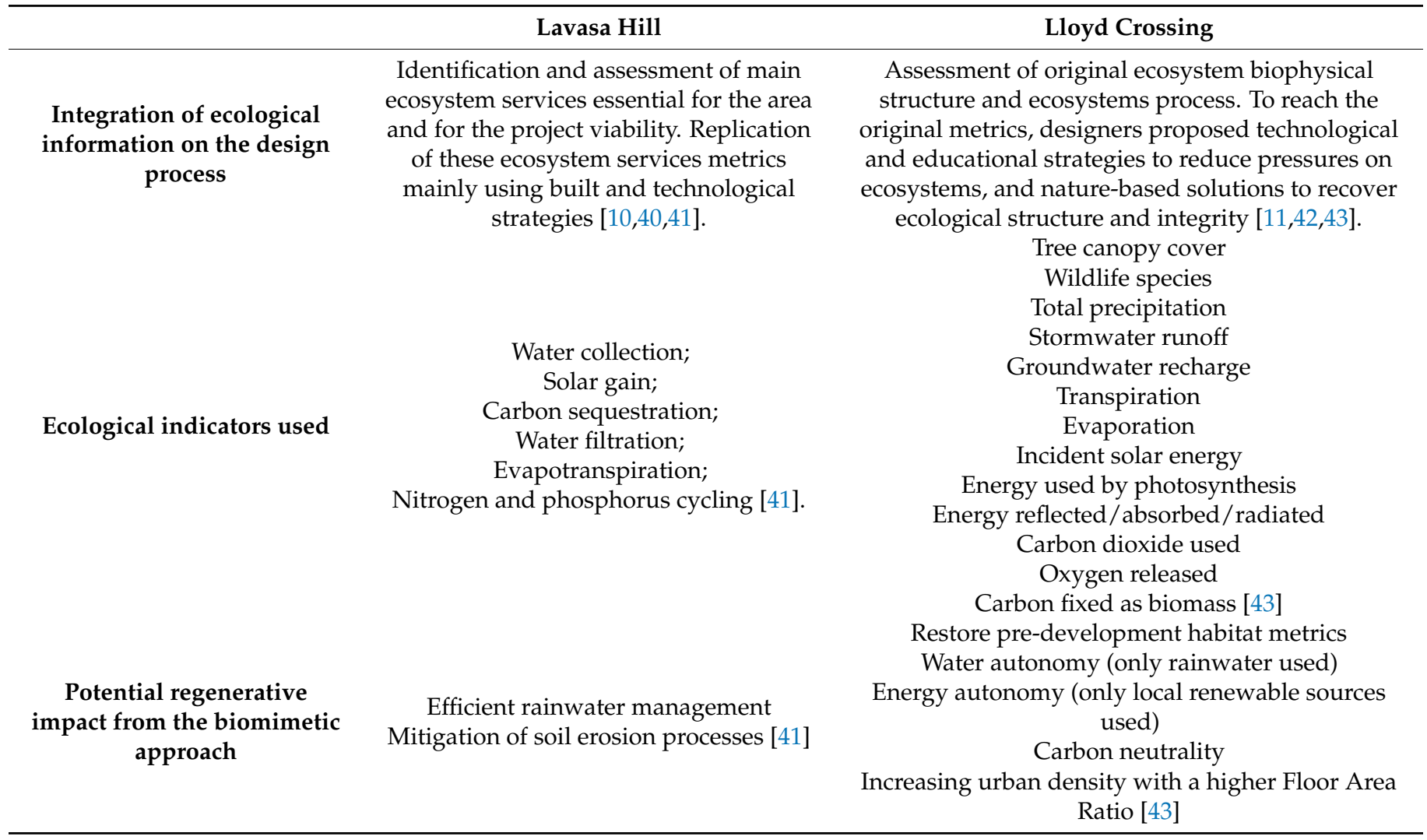

Source: Developed by the authors.

\section{Discussion}

Once we analyse these two projects from the perspective of ecosystem functioning, it is possible to observe that while both are innovative and pushing the boundaries of ecological design, they understand and use ecological information in different ways. Table 2 summarizes key information about the projects and their biomimetic approaches.

The Lavasa Hill project started by selecting a few relevant ecosystem services to the urban project, and the Lloyd Crossing project began with an analysis of the site's biophysical structure. From the perspective of the ecosystem services cascade, the Indian project places its focus on the social elements of the cascade, i.e., the benefits that society can perceive from a functional ecosystem. The US project focuses on the ecological, biophysical structure that is necessary to promote a healthier ecological system and, by consequence, a healthier social system. The main difference here relies on Lloyd Crossing project's understanding that benefits from nature are a consequence of the project, acting actively to improve the integrity of these ecosystems.

In this vein, we can also note a difference in the holistic comprehension of site patterns. The Lavasa Hill project mostly concentrates on water flows, a challenge identified for the site in terms of erosion and flood flows. This is an important focus for the project of course, but other ecological structures, processes, and functions are also important and relate holistically to the challenges of a city located on steep hills straddling a river that must cope with monsoon rains. The Lloyd Crossing project deals with ecosystem complexity holistically as a basis for devising initial project performance goals. It addresses biodiversity, physical ecological structure, and energy and material flows. Specifically in the Lloyd Crossing project, we can observe that the thirteen indicators used for ecological diagnostics correlate roughly to the ecological integrity criteria proposed by Kandziora et al., as shown in Table 3. 
Table 3. Elements of the ecological diagnosis carried out on the Lloyd Crossing project classified with the ecological integrity criteria proposed by Kandziora et al. [36].

\begin{tabular}{ccc}
\hline$\#$ & Pre-Development Metrics & Related Ecological Integrity Criteria \\
\hline 1 & Tree cover & Exergy capture/Entropy production \\
2 & Wildlife species & Biotic diversity \\
3 & Total precipitation & Water flows (abiotic) \\
4 & Stormwater runoff & Water flows (abiotic) \\
5 & Groundwater recharge & Water flows (abiotic) \\
6 & Transpiration & Water flows (biotic) \\
7 & Evaporation & Water flows (abiotic) \\
8 & Incident solar energy & Exergy capture \\
9 & Energy used by photosynthesis & Exergy capture/Entropy production \\
10 & Energy reflected/absorbed/radiated & Exergy capture \\
11 & CO 2 used & Exergy capture/Entropy \\
12 & Oxygen released & production/Metabolic efficiency \\
13 & Carbon fixed as biomass & Metabolic efficiency \\
\hline
\end{tabular}

Source: Developed by the authors based on [43].

Even if some of these indicators, like biodiversity, were not thoroughly evaluated during the diagnostic phase, because secondary data on wildlife and vegetation coverage was mostly used, the process promoted a good understanding of ecosystem functioning and the potential production of inherent benefits.

Although more aligned with the ecological integrity concept and with the ecosystem services cascade, most of the metrics and strategies explored at Lloyd Crossing were those related to water and energy flows, and carbon storage. Much like the concentration on water flows observed on the Lavasa Hill project, this focus shows us that projects applying ecosystem-level biomimicry to generate regenerative impacts still tend to lack integrating strategies related to the biological and abiotic structure of these ecosystems. This links to urban metabolism theories $[44,45]$ which concentrate on energy and material flows but do not give attention to biodiversity or the role of non-living structures in ecosystems which are crucial to ecosystem health, and therefore the production of ecosystem services that humans are dependent on [46].

It is also possible to identify in both projects that the strategies employed relate to ecosystems in two different ways: $1 /$ reducing built environment caused pressures on ecosystem structures, processes, and functions; and 2/recovering or regenerating ecosystem structures. Pressure reduction actions included reducing energy and water consumption, the greenhouse gas emissions reduction plan in the Lloyd Crossing project and managing rainwater in the Lavasa Hill project. Among the actions to regenerate ecosystem structures, the recovery of the green canopy and blue and green grid connectivity were key in the Lloyd Crossing proposal [43], as was massive reforestation plans that were part of the Lavasa Hill project. Regarding the ecosystem services cascade, these conjoint actions can increase ecosystem self-organisation capacity (or integrity) and thus potentially increase potential ecosystem services supply [36], and achieve, therefore, the positive ecological impacts that were set as project goals.

Though certainly innovative, and definitely ecosystem-services based, the Lavasa Hill project demonstrates a partial approach to understanding local ecosystems and using these as a design driver. In contrast, the Lloyd Crossing project finds a conceptual base for both design strategies and performance goals in the ecological metrics assessed during the pre-development diagnostic phase, changing the design starting point, and integrating more in-depth ecological knowledge into the design [11,42]. This allows Lloyd Crossing to become a neighbourhood that works in more similar ways to local ecosystem patterns, and to become a district that generates benefits for humans and local ecosystems. This ties in with the regenerative notion of creating potentially positive and symbiotic impacts on local socio-ecosystems through development, not despite it. 


\section{Conclusions}

To move forward with ecosystem-level biomimicry for regenerative urban design, it is essential to integrate understanding of local ecological structures, processes, and functions into design phases. The ecosystem services concept is an interesting entry point, but merely estimating ecosystem services provision guides us to an overly simplistic comprehension of ecosystems. In an ecosystem-level biomimetic approach, the ecosystem biophysical structure and its related processes allow a better comprehension of how ecosystems work, that can guide urban design processes. Our two case studies support this argument.

Compared to previous sustainable urban design frameworks, ecosystem-level biomimicry for regenerative design offers an opportunity to integrate ecology knowledge with urban design deeply. However, our case studies confirm the absence of consistent comprehension and integration of ecological theories into current urban design processes and practice. We also observed that the two analysed projects focus on addressing energy and material (mainly water) flows and lack understanding of other essential ecosystem criteria that are crucial for the dynamic stability of ecosystem services provision, such as biodiversity $[3,36]$.

As Odum described [28], an ecosystem has a biological structure, physical abiotic structures, and material and energy flows. These four elements must be addressed in ecosystem-biomimetic and regenerative urban design if the aim is to concurrently improve society's wellbeing and the integrity of ecological systems.

Finally, the Pedersen Zari framework, as well the two case studies highlight that undertaking a comprehensive socio-ecological diagnostic process before any urban design or performance goal conception should be an unavoidable part of regenerative and biomimetic urban projects. This converges with other environmental management theories such as Strategic Environmental Assessment [47] and Cross Diagnostics [48].

This review sheds light on research questions that could help to scale up the application of ecosystem services-based biomimicry frameworks and regenerative design practices at the urban scale. Some of these questions are:

(1) How are the regeneration and the ecosystem goals of these projects translated into technical solutions? Which strategies can projects implement to work toward humandesigned ecosystem services provision and to catalyse socio-ecosystems regeneration and co-evolution?

(2) How do regenerative projects draw on ecosystem functioning? Which ecological information and concepts are useful to urban designers to understand ecosystem functioning better and promote ecosystem regeneration?

(3) How are the outcomes of such projects measured and monitored? Which ecological indicators do projects use to assess the impact of regenerative design on local ecosystems?

(4) How do urban project phasing and stakeholder roles take account of and influence ecosystem properties and the overall ecological performance of a project?

In conclusion, the main finding from this research is that although theories related to ecosystem functioning are starting to be used in urban design and planning settings, there is still room for improvement. Integrating up to date, high quality ecology knowledge into the theoretical basis of these ecosystem-based design concepts and methods along with increased interdisciplinary work in both the conception of and application of these concepts and methods is likely to be key.

Author Contributions: Conceptualization, E.B., P.C. and K.R.; methodology, E.B. and P.C.; formal analysis, E.B.; investigation, E.B.; writing-original draft preparation, E.B.; writing-review and editing, P.C., K.R. and M.P.Z.; supervision, P.C.; funding acquisition, E.B and K.R. All authors have read and agreed to the published version of the manuscript.

Funding: This research was funded by ANRT, grant number CIFRE 2019/0389.

Institutional Review Board Statement: Not applicable.

Informed Consent Statement: Not applicable. 
Data Availability Statement: No new data were created or analyzed in this study. Data sharing is not applicable to this article.

Conflicts of Interest: The authors declare no conflict of interest. The funders had no role in the design of the study; in the collection, analyses, or interpretation of data; in the writing of the manuscript, or in the decision to publish the results.

\section{References}

1. United Nations-Department of Economic and Social Affairs-Population Division. World Urbanization Prospects: The 2018 Revision (ST/ESA/SER.A/420); United Nations: New York, NY, USA, 2019; Volume 12, ISBN 9789211483192.

2. Alberti, M. The effects of urban patterns on ecosystem function. Int. Reg. Sci. Rev. 2005, 28, 168-192. [CrossRef]

3. Millenium Ecosystem Assessment. Ecosystems and Human Well-Being: Synthesis; Island Press: Washington, DC, USA, 2005; ISBN 1597260401.

4. Brown, M.; Haselsteiner, E.; Apró, D.; Kopeva, D.; Lucas, E.; Pulkkinen, K.; Vula Rizvanolli, B. Sustainability, Restorative to Regenerative. COST Action CA16114 RESTORE, Working Group One Report: Restorative Sustainability; Eurac Research: Bolzano, Italy, 2018.

5. Cole, R.J. Regenerative design and development: Current theory and practice. Build. Res. Inf. 2012, 58, 1-6. [CrossRef]

6. Pedersen Zari, M. Mimicking ecosystems for bio-inspired intelligent urban built environments. Intell. Build. Int. 2016, 8, 57-77. [CrossRef]

7. Hayes, S.; Desha, C.; Gibbs, M. Findings of case-study analysis: System-Level biomimicry in built-environment design. Biomimetics 2019, 4, 73. [CrossRef]

8. ISO. ISO 18458:2015-Biomimetics-Terminology, Concepts and Methodology; ISO: Geneva, Switzerland, 2015.

9. Chayaamor-Heil, N.; Guéna, F.; Hannachi-Belkadi, N. Biomimétisme en architecture. État, méthodes et outils. Les Cah. Rech. Archit. Urbaine Paysag. 2018, 1, 0-33. [CrossRef]

10. Buck, N.T. The art of imitating life: The potential contribution of biomimicry in shaping the future of our cities. Environ. Plan. B Urban Anal. City Sci. 2017, 44, 120-140. [CrossRef]

11. Pedersen Zari, M. Regenerative Urban Design and Ecosystem Biomimicry; Routledge: London, UK, 2018 ; ISBN 978113807.

12. Uchiyama, Y.; Blanco, E.; Kohsaka, R. Application of biomimetics to architectural and urban design: A review across scales. Sustainability 2020, 12, 9813. [CrossRef]

13. Baumeister, D.; Pedersen Zari, M.; Hayes, S. Biomimicry: An Opportunity to Relate to Place. In Ecologies Design: Transforming Architecture, Landscape, and Urbanism; Pedersen Zari, M., Conolly, P., Southcombe, M., Eds.; Routledge: Abingdon, UK, 2020.

14. Zhang, X.; Skitmore, M.; De Jong, M.; Huisingh, D.; Gray, M. Regenerative sustainability for the built environment-From vision to reality: An introductory chapter. J. Clean. Prod. 2015, 109, 1-10. [CrossRef]

15. Hes, D.; Stephan, A.; Moosavi, S. Evaluating the practice and outcomes of applying regenerative development to a large-scale project in Victoria, Australia. Sustainability 2018, 10, 460. [CrossRef]

16. Gibbons, L.V.; Pearthree, G.; Cloutier, S.A.; Ehlenz, M.M. The development, application, and refinement of a Regenerative Development Evaluation Tool and indicators. Ecol. Indic. 2020, 108, 105698. [CrossRef]

17. Krippendorff, K. Content Analysis: An Introduction to its Methodology, 2nd ed.; Sage Publications: Thousand Oaks, CA, USA, 2004; ISBN 0761915443.

18. Francis, M. A Case Study Method For Landscape Architecture. Landsc. J. 2001, 20, 15-29. [CrossRef]

19. Groat, L.; Wang, D. Architectural Research Methods; John Wiley \& Sons: Hoboken, NJ, USA, 2013; ISBN 9780470908556.

20. Steiner, F.; Young, G.; Zube, E. Ecological Planning: Retrospect and Prospect. In The Ecological Design and Planning Reader; Ndubisi, F.O., Ed.; Island Press/Center for Resource Economics: Washington, DC, USA, 2014; pp. 72-90. ISBN 978-1-61091-491-8.

21. Pickett, S.T.A.; Cadenasso, M.L.; Grove, J.M.; Nilon, C.H.; Pouyat, R.V.; Zipperer, W.C.; Costanza, R. Urban ecological systems: Linking terrestrial ecological, physical, and socioeconomic components of metropolitan areas. Urban Ecol. Int. Perspect. Interact. Hum. Nat. 2008, 99-122. [CrossRef]

22. Steiner, F. Frontiers in urban ecological design and planning research. Landsc. Urban Plan. 2014, 125, 304-311. [CrossRef]

23. McHarg, I.L. Design with Nature; John Wiley \& Sons: Hoboken, NJ, USA, 1969.

24. Ndubisi, F. Ecological Planning: A Historical and Comparative Synthesis; Johns Hopkins University Press: Baltimore, MD, USA, 2002.

25. Harrison, P.A.; Dunford, R.; Barton, D.N.; Kelemen, E.; Martín-López, B.; Norton, L.; Termansen, M.; Saarikoski, H.; Hendriks, K.; Gómez-Baggethun, E.; et al. Selecting methods for ecosystem service assessment: A decision tree approach. Ecosyst. Serv. 2018, 29, 481-498. [CrossRef]

26. Lyle, J.T. Regenerative Design for Sustainable Development; John Wileys \& Sons, Inc.: Hoboken, NJ, USA, 1994.

27. Reed, B. Shifting from "sustainability" to regeneration. Build. Res. Inf. 2007, 35, 674-680. [CrossRef]

28. Odum, E.P. The strategy of ecosystem development. Science 1969, 164, 262-270. [CrossRef]

29. Costanza, R.; D'Arge, R.; de Groot, R.; Farber, S.; Grasso, M.; Hannon, B.; Limburg, K.; Naeem, S.; O’Neil, R.V.; Paruelo, J.; et al. The value of the world's ecosystem services and natural capital. Nature 1997, 387, 253-260. [CrossRef]

30. Potschin, M.; Haines-Young, R.; Görg, C.; Heink, U.; Jax, K.; Schleyer, C. Understanding the role of conceptual frameworks: Reading the ecosystem service cascade. Ecosyst. Serv. 2018, 29, 428-440. [CrossRef] 
31. Czúcz, B.; Arany, I.; Potschin-young, M.; Bereczki, K.; Kertész, M.; Kiss, M.; Aszalós, R.; Haines-young, R. Where concepts meet the real world: A systematic review of ecosystem service indicators and their classification using CICES. Ecosyst. Serv. 2018, 29, 145-157. [CrossRef]

32. Haase, D.; Larondelle, N.; Andersson, E.; Artmann, M.; Borgström, S.; Breuste, J.; Gomez-Baggethun, E.; Gren, Å.; Hamstead, Z.; Hansen, R.; et al. A quantitative review of urban ecosystem service assessments: Concepts, models, and implementation. Ambio 2014, 43, 413-433. [CrossRef]

33. Luederitz, C.; Brink, E.; Gralla, F.; Hermelingmeier, V.; Meyer, M.; Niven, L.; Panzer, L.; Partelow, S.; Rau, A.L.; Sasaki, R.; et al. A review of urban ecosystem services: Six key challenges for future research. Ecosyst. Serv. 2015, 14, 98-112. [CrossRef]

34. Haines-Young, R.; Potschin, M. The links between biodiversity, ecosystem services and human well-being. Ecosyst. Ecol. New Synth. 2010, 1, 110-139. [CrossRef]

35. La Notte, A.; D'Amato, D.; Mäkinen, H.; Paracchini, M.L.; Liquete, C.; Egoh, B.; Geneletti, D.; Crossman, N.D. Ecosystem services classification: A systems ecology perspective of the cascade framework. Ecol. Indic. 2017, 74, 392-402. [CrossRef] [PubMed]

36. Kandziora, M.; Burkhard, B.; Müller, F. Interactions of ecosystem properties, ecosystem integrity and ecosystem service indicators: A theoretical matrix exercise. Ecol. Indic. 2013, 28, 54-78. [CrossRef]

37. Müller, F. Indicating ecosystem and landscape organisation. Ecol. Indic. 2005, 5, 280-294. [CrossRef]

38. Gómez-Baggethun, E.; Barton, D.N. Classifying and valuing ecosystem services for urban planning. Ecol. Econ. 2013, 86, 235-245. [CrossRef]

39. Suchocka, M.; Błaszczyk, M.; Juźwiak, A.; Duriasz, J.; Bohdan, A.; Stolarczyk, J. Transit versus Nature. Depreciation of Environmental Values of the Road Alleys. Case Study: Gamerki-Jonkowo, Poland. Sustainability 2019, 11, 1816. [CrossRef]

40. Datta, A. India's ecocity? environment, urbanisation, and mobility in the making of Lavasa. Environ. Plan. C Gov. Policy 2012, 30, 982-996. [CrossRef]

41. Lazarus, M.A.; Crawford, C. Returning Genius to the Place. Archit. Des. 2011, 86, 48-53. [CrossRef]

42. Hayter, J.A. Lloyd Crossing Sustainable Urban Design Plan and Catalyst Project-Portland, Oregon. Places 2005, $17,14-17$.

43. Mithūn. Lloyd Crossing-Sustainable Urban Design Plan \& Catalyst Project; Mithūn Inc.: Seattle, WA, USA, 2004.

44. Thomson, G.; Newman, P. Urban fabrics and urban metabolism-From sustainable to regenerative cities. Resour. Conserv. Recycl. 2018, 132, 218-229. [CrossRef]

45. Elliot, T.; Almenar, J.B.; Niza, S.; Proença, V.; Rugani, B. Pathways to modelling ecosystem services within an urban metabolism framework. Sustainability 2019, 11, 2766. [CrossRef]

46. Golubiewski, N. Is there a metabolism of an urban ecosystem? An ecological critique. Ambio 2012, 41, 751-764. [CrossRef]

47. Thérivel, R.; Caratti, P.; Partidärio, M.D.R.; Theodórsdóttir, Á.H.; Tyldesley, D. Writing strategic environmental assessment guidance. Impact Assess. Proj. Apprais. 2004, 22, 259-270. [CrossRef]

48. Clergeau, P. La biodiversité dans les stratégies d'améNagement Urbain. Available online: https://www.metropolitiques.eu/Labiodiversite-dans-les-strategies-d-amenagement-urbain.html (accessed on 19 August 2020). 